\title{
Modeling population dynamics of solitary bees in relation to habitat quality
}

\author{
Karin Ulbrich and Karsten Seidelmann
}

Ulbrich, K. and Seidelmann, K. 2001. Modeling population dynamics of solitary bees in relation to habitat quality. - Web. Ecol. 2: 57-64.

\begin{abstract}
To understand associations between habitat, individual behaviour, and population development of solitary bees we developed an individual-based model. This model is based on field observations of Osmia rufa (L) (Apoideae: Megachilidae) and describes population dynamics of solitary bees. Model rules are focused on maternal investment, in particular on the female's individual decisions about sex and size of progeny. In the present paper, we address the effect of habitat quality on population size and sex ratio. We examine how food availability and the risk of parasitism influence long-term population development. It can be shown how population properties result from individual maternal investment which is described as a functional response to fluctuations of environmental conditions. We found that habitat quality can be expressed in terms of cell construction time. This interface factor influences the rate of open cell parasitism as the risk for a brood cell to be parasitized is positively correlated with the time of its construction. Under conditions of scarce food and under resulting long provision times even low parasitism rates lead to a high extinction risk of the population, whereas in rich habitats probabilities of extinction are low even for high rates of parasitism. For a given level of food and parasitism there is an optimum time for cell construction which minimizes the extinction risk of the population. Model results demonstrate that under fluctuating environmental conditions, decreasing habitat quality leads to a decrease in population size but also to rapid shifts in sex ratio.
\end{abstract}

K.Ulbrich (ulbrich@zoologie.uni-halle.de) and K. Seidelmann, Institute for Zoology, Univ. of Halle, Domplatz 4, D-06099 Halle, Germany.

Interactions between individuals and the habitat are known to have profound impacts on population dynamics. Our study directs the focus towards the issues of habitat quality, individual variability, behaviour, and population development. Modeling those interrelationships can help to understand which biological and ecological processes are essential for population response to habitat changes (Begon et al. 1990). In addition, long-term studies allow us to investigate separately the impact of habitat properties on the extinction risk of the population. Such questions cannot be examined in the field. Based on field studies of the red mason bee Osmia rufa (L.) (Apoideae:
Megachilidae), we developed the first individual-based model for solitary bees which stresses maternal investment (Ulbrich and Seidelmann 1998, Ulbrich et al. 1999). We chose an individual-based model approach because a fundamental significance of the individual variability of bees was suspected, in particular with respect to population persistence (DeAngelis et al. 1994, Grimm et al. 1999). A similar model approach had been successfully applied to social spiders (Ulbrich and Henschel 1999), where individual variability and food allocation were described in relation to habitat quality.

Our field results for $O$. rufa showed that the individual 
variability in female body mass had a considerable impact on the reproductive output of the population as large bees produced more and larger daughters than small bees do. These findings were included into our model rules. In the present paper, we focus on the influence of habitat quality on population dynamics. Our first step of modeling was to identify the components of habitat quality which have essential impact on the maternal investment and the reproductive success of individual female bees. Secondly, individual life histories had to be linked to population dynamics.

Solitary bees are suitable subjects of study with respect to reproductive behaviour as they have immediate control both over sex and size of each offspring. They control the sex by fertilizing the egg or not and they control the size by the amount of food which they store in the cell. The fecundity of female bees is limited by this high investment and depends on their capability to build and provision cells. Nest-constructing solitary bees are mass provisioners with exclusive maternal investment in brood care. Pollen and nectar in this provision are the only food source for the whole development of the progeny. Therefore, the availability of food plants has direct impact both on the physiological condition of adult bees and the offspring. Food availability may depend on factors such as a) the distances between nesting sites and food plants as well as flower density, b) the food quality (e.g. protein content and flower productivity) and c) competition with other species (Westrich 1989). Nesting sites constitute another limiting resource for solitary bees. Females of stem-, twig- or holenesting, xylophilous bees are not able to excavate cavities to form nests. They depend on finding a suitable hollow twig or a bore hole of a beetle in dead wood, and often nesting places are rare resources for these species (Danks 1971, Tepedino and Torchio 1989).

In most solitary bees, brood parasitism is the main mortality factor (Krombein 1967, Brechtel 1986, Westrich 1989), inflicting high fitness losses on females. Parasites either attack sealed cells or open cells. The success of parasites which attack sealed cells after nest closure depends only on the thickness and material of the nesting tube. Another group of parasites attack open nests during the collecting flights of the mother bee. Females are not able to prevent those attacks on open cells during their collecting flights (Seidelmann 1999), therefore, the "open-cell parasitism" is a main factor affecting habitat quality. Without any doubt, components of habitat quality, such as the availability of food and nesting sites as well as parasitism, contribute directly to the individual reproductive success of female bees. It is not known, however, how these factors influence number, sex ratio, and size of progeny.

Thus, the objectives of the present paper are 1) to derive model rules which express the impact of habitat quality (in particular: food availability and parasitism) on population dynamics of solitary bees, 2) to question whether fluctuations of population size and sex ratio can be understood as responses of individual maternal investment to fluctuations of habitat quality, 3) to assess the impact of habitat quality on long-term population dynamics and extinction risk.

\section{Biological background and field measurements}

The red mason bee Osmia rufa (Syn.: O. bicornis) (Hymenoptera: Megachilidae), a protandrous, univoltine, polylectic, twig-nesting bee is one of the most common solitary bees in Europe. Osmia rufa is regarded as a generalist among solitary bees. Its biology and ecology are well studied (Raw 1972, Seidelmann 1995). The bees emerge in April, males one to two weeks before females. After mating, females start nest construction and complete several nests by the end of May or mid-June. Females construct brood cells in a linear succession in an empty hole. They store pollen and nectar as larval food and lay one egg per cell before sealing it. Young larvae develop inside their cells and hatch to the imago in late summer, but they stay inside their cocoon until spring.

Field observations were carried out from 1990 to 1999 in the Botanical Garden of the Univ. of Halle (Saale). Artificial nests of various materials and dimensions were offered to the bees. We observed individual nesting behaviour and nesting success by weighing and labeling females with commercial honey-bee tags. During the following winter the nests were opened and analyzed, size and content were recorded for all cells. Based on the strong correlation between cocoon mass and bee bread mass (Phillips and Klostermeyer 1978, Maddocks and Paulus 1987, Danforth 1990), we used the weight of the cocoon containing the young bee as a measure for the provision mass which the mother bee had collected and stored in the cell.

\section{The model}

Our individual-based model "HIP" (Habitat-IndividualPopulation) describes the fate of each individual from birth to death distinguishing the life stages "Egg", "Larva", "Imago in the cocoon", "Males", "Prenesting females", and "Nesting females" (Ulbrich and Seidelmann unpubl.).

The main part of the model algorithm deals with maternal investment in brood cells (Fig. 1). This algorithm is based on following assumptions and rules.

\section{Sex of progeny}

The female bee determines the sex of her progeny by fertilizing the egg or not. Brood cells are built in a linear succession starting with daughter cells. The bee has to decide how many daughter cells to build, before she switches to the construction of son cells. In agreement with our field results for $O$. 


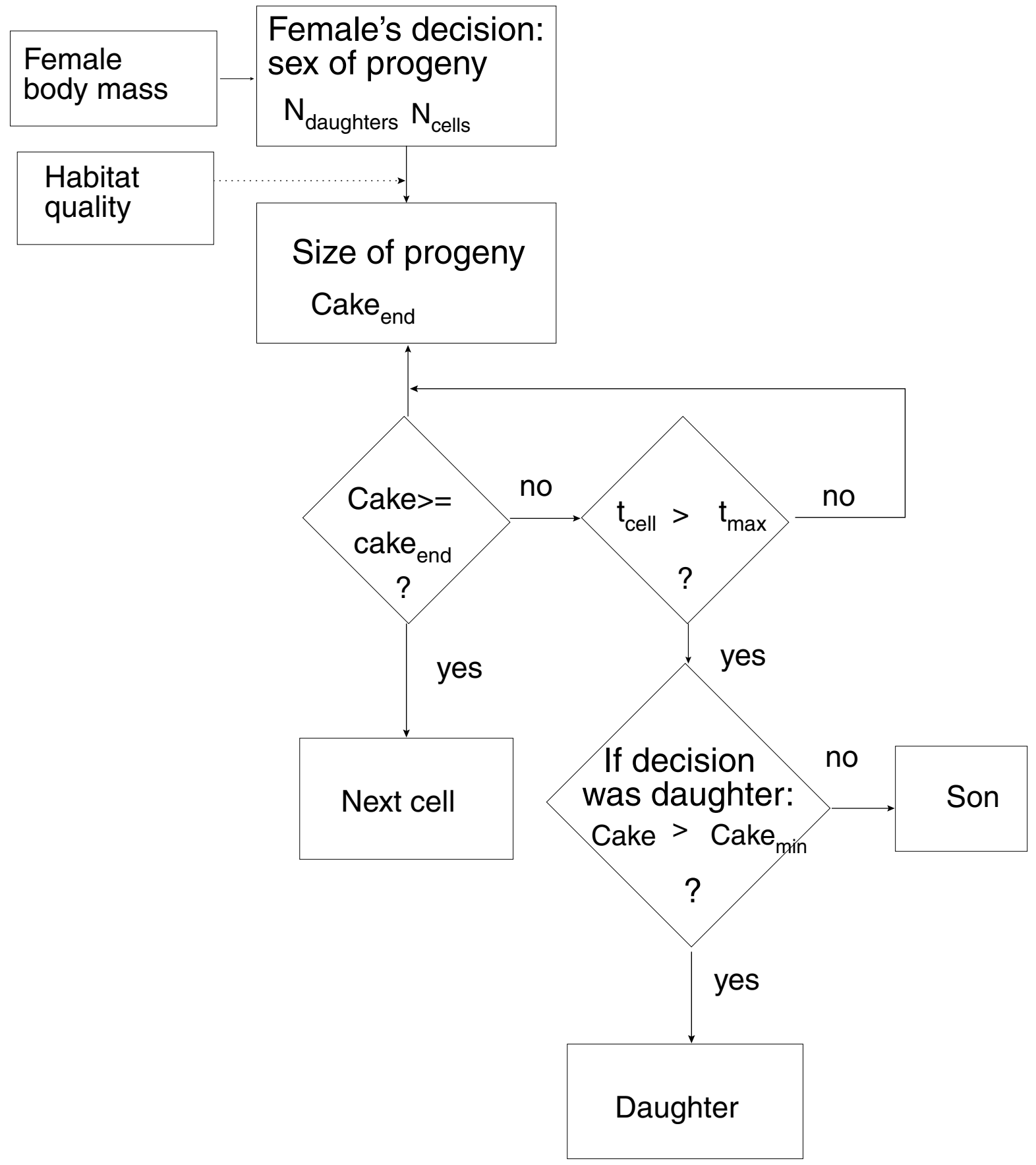

Fig. 1. Model algorithm describing maternal investment. 
rufa, we assumed that the number of daughters $\mathrm{N}_{\text {daughters, }}$ is correlated to the female body mass mass mo,i . The coefficient $\mathrm{c} 1$ was 0.33 for the first nest and 0.25 for subsequent nests.

$$
\mathrm{N}_{\text {daughters,i }}=\mathrm{cl}^{*} \text { mass }_{\mathrm{mo}, \mathrm{i}}
$$

\section{Size of progeny}

We found for $O$. rufa that the body mass of female progeny is correlated with the mother bee's body mass. We assumed that the size of progeny results from the provisions collected by the bee. Under favourable environmental conditions the mass of provisions cake $e_{\text {end,i }}$ is determined only by the female body mass:

$$
\text { cake }_{\text {end,i }}=\text { mass }_{\text {mo,i }}+\varphi_{\text {cake, },}
$$

The random function $\varphi_{\text {cake }}$ defines the range of devia-

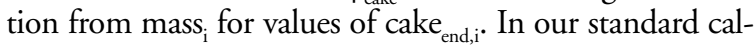
culations, $\varphi_{\text {cake }}$ had values between -13 and 8 . The mass of progeny mass pri, $_{\text {is }}$ directly related to cake $e_{\text {end }, \mathrm{i}}$ :

$$
\text { mass }_{\mathrm{pri \textrm {i }}}=\mathrm{c} 2^{*} \text { cake }_{\mathrm{end}, \mathrm{i}}
$$

\section{Time of cell construction}

Gathmann (1998) found for O. caerulescens and Megachile versicolor that times for collecting flights differed between habitats with different quality. Corresponding to our field results, the time of cell construction does not depend significantly on females' body mass though the size of cells does. Therefore, the parameter "time necessary for complete construction" $t_{\text {compl }}$ was used as a habitat parameter. We assume that a bee needs the time $t_{\text {compl }}$ to provide a brood cell with the provisions cake $e_{\text {end,i }}$ according to eq. 2 . In our standard simulations, $t_{\text {compl }}$ amounts to one day in rich habitats (Seidelmann 1995).

\section{Influence of habitat quality on size of progeny}

The "real time of cell construction" $t_{\text {real }}$ may differ from $t_{\text {compl }}$ under adverse conditions. We assume that the bee seals the brood cell after a time $t_{\text {max }}$ (e.g. to limit the risk of parasitism). If provisioning was not completed during this time, the amount of provisions would be less than cake ${ }_{\text {end,i }}$ and the progeny size would decrease.

\section{Influence of habitat quality on sex of progeny}

If the amount of provisions collected by the mother bee is less than a threshold value cake ${ }_{\text {min }}$, only a son can develop.

\section{Occupation of a new nest}

After constructing a certain number of cells (e.g. 7 to 11 cells) the nest is closed and the bee will search for the next nesting hole. The more holes are occupied by conspecific bees, the lower the probability of nest occupation for an individual female. By this way, we describe regulation of population density.

The program used for implementation was $\mathrm{C}++_{+}$. The time step was one day, as processes such as cell construction and egg deposition have been examined daily.

\section{Results}

Mean population size was taken as a criterion to assess the impact of habitat quality on population development and, ultimately, on the extinction risk. It becomes obvious that the extinction risk of small populations would be higher than that of large ones under conditions of weather fluctuations or negative habitat changes (e.g. due to agricultural management). The influence of the parasitism risk (which means the probability of a brood cell to be parasitized) on mean population size was plotted for various food levels (Fig. 2). The values 1, 2, 3, and 4 for the parameter $t_{\text {compl }}$ correspond to the food levels "very good", "good", "medium", and "bad" (see model rule 3). Even a low parasitism risk leads to a dramatic decrease of the mean population size under conditions of food scarcity (Fig. 2). Contrarily, in rich habitats the influence of parasitism on population size is small. Population size was averaged over $200 \mathrm{yr}$.

Furthermore, mean population size was plotted versus the real time of cell construction $t_{\text {real }}$ for various risks of parasitism (Fig. 3). The time necessary to complete cell construction $\mathrm{t}_{\text {compl }}$ was $3 \mathrm{~d}$ if habitat quality was "medium". If bees seal the cell earlier $\left(t_{\text {real }}<t_{\text {comp }}\right)$, the population size decreases rapidly independently of the risk of parasitism. The reason of extinction under conditions of $\left(t_{\text {real }}<t_{\text {compl }}\right)$ were both the low number of progeny and the distorted sex ratio. On the other hand, if bees seal the cell late $\left(\mathrm{t}_{\text {compl }}>\right.$ $\left.t_{\max }\right)$ the decrease of population size results from the increasing rate of parasitism. The existence of a maximum in all 3 curves demonstrates that there is an optimum value for $t_{\text {real }}$.

The behaviour of the model population in a non-constant environment was shown at Fig. 4. Population size and sex ratio were calculated while varying habitat quality from year to year. Under "bad" conditions population size decreases rapidly and sex ratio shifts towards males. The population can return to equilibrium under "good" and "medium" conditions. However, the higher the frequency of "bad" conditions the lower the population size and the higher the extinction risk. 
Fig. 2. Mean population size in over 100 simulations versus risks of parasitism (probability that a brood cell will be parasitized). The scenarios differ with regard to the level of food availability which was described by the number of days needed for the provision of one daughter cell. 1 : rich habitat $(1 \mathrm{~d}), 2$ : medium (2 d), 3: poor (3 d), 4: very poor habitat ( $4 \mathrm{~d})$.

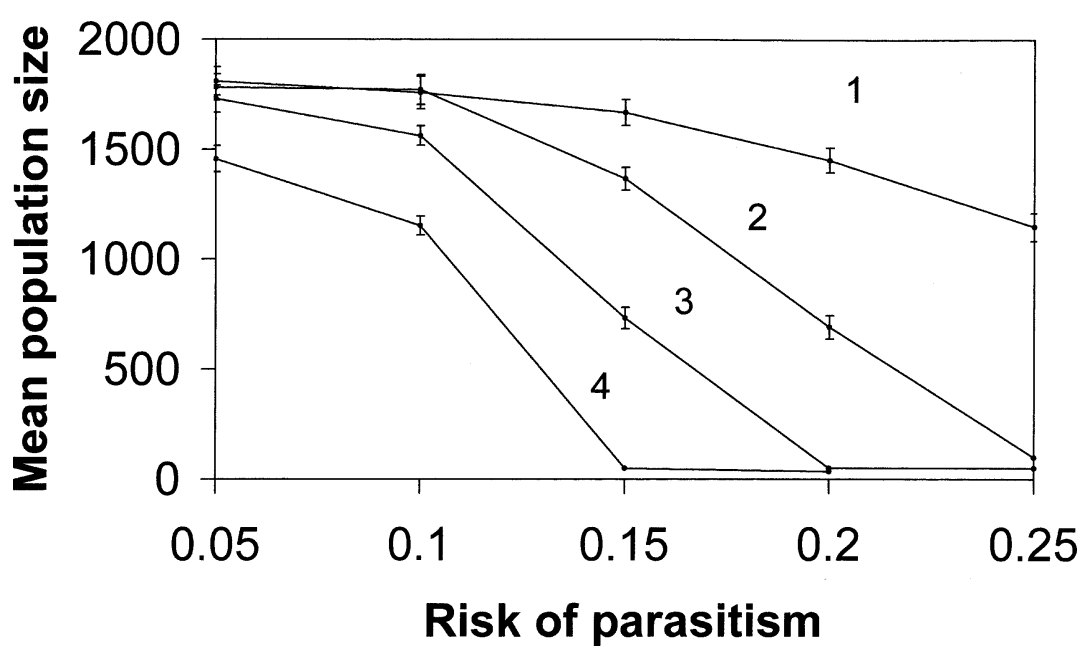

amount of food they store in the cell (Fig. 1). However, mother bees cannot independently vary size and sex of progeny as each investment decision represents a tradeoff between size and sex of offspring and the total number of progeny. Modelling those decisions of the bee, we assumed that both number and sex ratio of progeny are related to female body mass (Rosenheim et al. 1996, Ulbrich et al. 1999) with large females having more and larger daughters than smaller ones. We found that cell provisioning, which is one of the main mutual influences between the bee and habitat, can be described with the help of the parameter "time of cell construction". The time a female bee needs to provision a single cell with a certain amount of food de-
Fig. 3. Mean population size in over 100 simulations versus time of cell construction $t_{\text {real }}$. The time needed for complete provisioning of one daughter cell $t_{\text {compl }}$ was $3 \mathrm{~d}$. The risk of parasitism (probability that a brood cell will be parasitized) was varied from 0.05 to 0.25 .

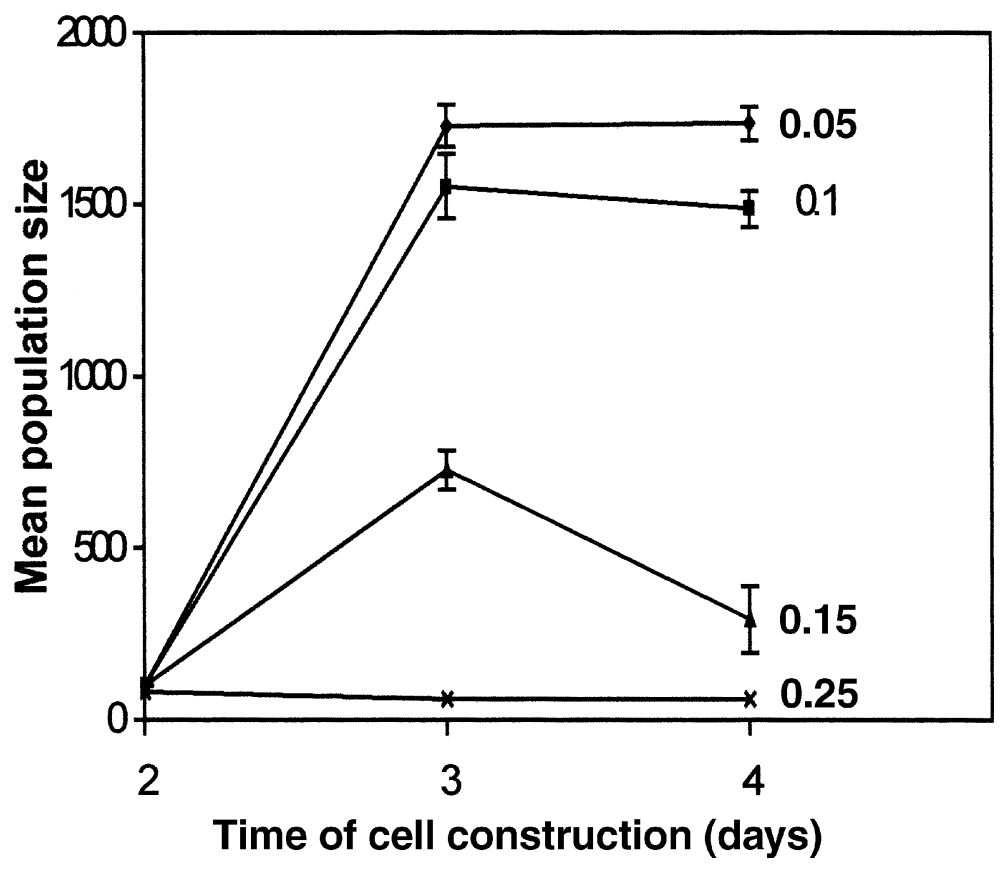



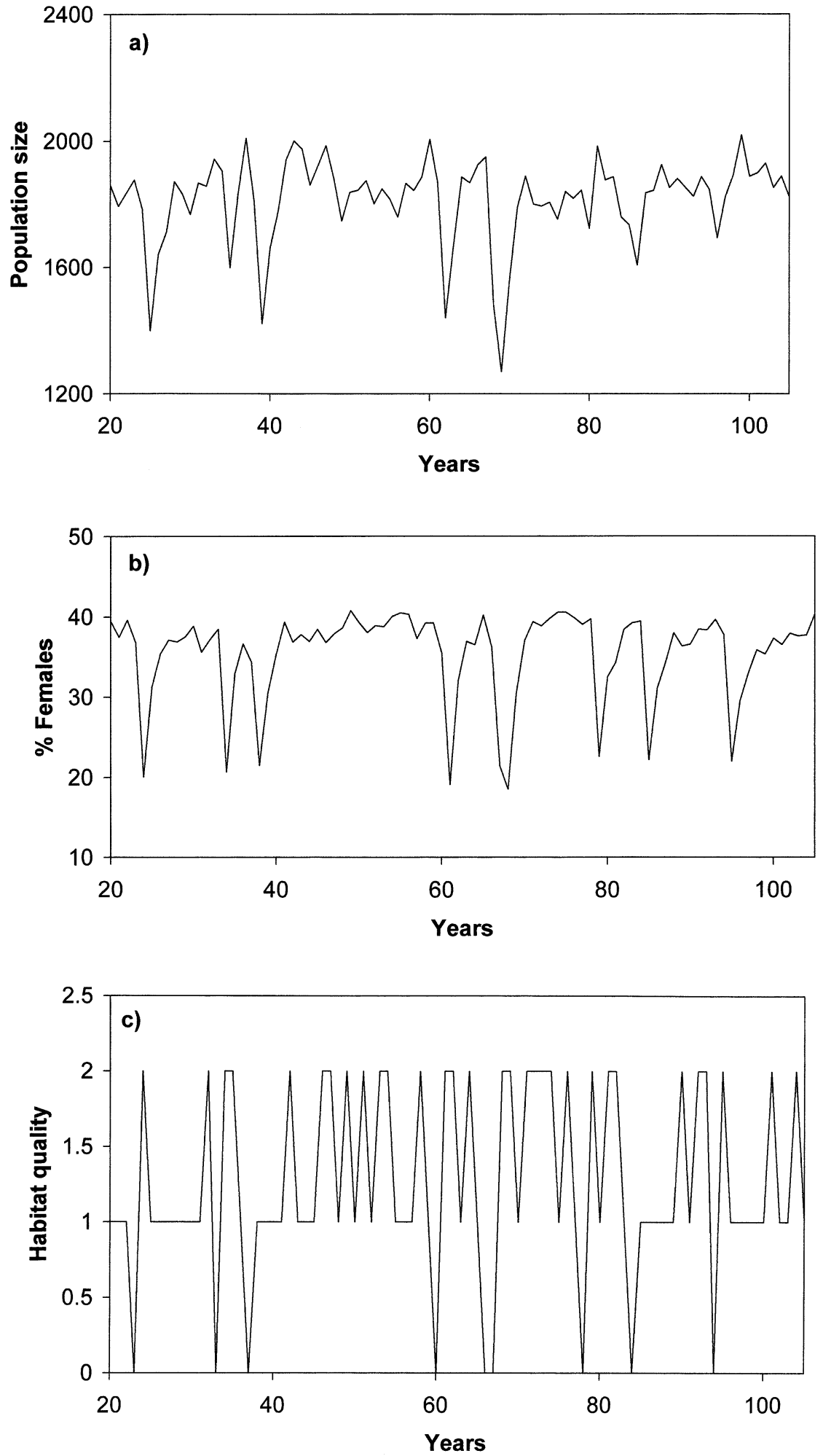

Fig. 4. Development of a solitary bee population in a heterogeneous environment a) population size; b) sex ratio; c) level of habitat quality. 
pends on the food availability in a particular habitat. Due to the dimorphism in body size, more time is necessary to provision a daughter cell than that of a son cell. On the other hand, the duration of cell provisioning is limited by the risk of open-cell parasitism. The probability for a $O$. rufa brood cell to become parasitized was found to be a linear function of provisioning time (unpubl.). Both factors, food availability as well as parasitism risk, influence maternal investment and, ultimately, population size (Fig. 2). Furthermore, they determine an optimum time for cell construction which is effectively a habitat parameter and does not depend on size or age of the female bee. It becomes obvious that this optimum time represents a compromise on the size (provisioned long enough) and number (part of the cells not parasitized) of progeny. Model calculations show that the adherence to this "optimum time of cell construction" results not only in the maximum fitness of individual female bees, but also in the maximum population size (Fig. 3).

Our model rules consider that daughters suffer more than sons from a time limitation (e.g. due to a low food level or a high parasitism risk) as they need more provision. Adverse conditions reduce not only their size but may also "change" their sex. If provisions amount less than a given threshold, the bee will produce sons instead of a daughter. As a result, progeny sex ratio will shift towards males. The reduced number of daughters as well as the reduced fertility of smaller daughters lower the reproductive potential of subsequent generations. This process may be amplified by adverse years which leads to low population sizes and, finally, to a high extinction risk (Fig. 4).

Our results suggest that the optimum time of cell construction is also the basis for the observed size-dependent provision strategies observed in O. rufa (Seidelmann 1995, Ulbrich et al. 1999). Obviously, small females produce more males because they collect less food per unit time. For a given time interval (e.g. for one day) large bees may collect sufficient provisions for a daughter cell, but small bees may only be able to provision a son cell. These findings fit well to the conditional sex allocation theory (Charnov 1982).

With this model, we described the impact of habitat quality on population dynamics of solitary bees with the help of a small set of relatively simple rules. Rules for maternal investment are based on field data for progeny size and sex ratio of individual females. Model calculations, however, link individual reproductive outputs to the population level. Thereby, our model "HIP" (Habitat-Individual-Population) allows us to obtain a more comprehensive understanding of population dynamics than models referring to average individuals. Model simulations demonstrate that not only population size but also the number and size of females are closely related to habitat quality. These results help to explain field studies which indicate a high variability of population properties such as population size, mean female body size, and sex ratio.
Acknowledgement - We thank V. Grimm for valuable discussions. The project was supported by the UFZ - Center for Environmental Research Leipzig-Halle GmbH.

\section{References}

Begon, M., Harper, J. L. and Townsend, C. R. 1990. Ecology (2nd ed.). - Blackwell.

Brechtel, F. 1986. Die Stechimmenfauna des Bienenwaldes und seiner Randbereiche Südpfalz unter besonderer Berücksichtigung der Ökologie kunstnestbewohnender Arten. - Pollichia, Bad.

Charnov, E. 1982. The theory of sex allocation. - Princeton Univ. Press.

Danforth, B. N. 1990. Provisioning behavior and the estimation of investment ratios in a solitary bee, Calliopsis (Hypomarotera) persimilis (Cockerell) (Hymenoptera: Andrenidae). Behav. Ecol. Sociobiol. 27: 159-168.

Danks, H. V. 1971. Populations and nesting sites of some aculeate Hymenoptera nesting in Rubus. - J. Anim. Ecol. 40: 63-77.

De Angelis, D. L., Rose, K. A. and Huston, M. A. 1994. Individual-oriented approaches to modeling ecological populations and communities. - In: Levin, S. A. (ed.), Frontiers in mathematical biology. Springer, pp. 390-410.

Gathmann, A., Greiler, H.-J. and Tscharntke, T. 1994. Trap-nesting bees and wasps colonizing set-aside fields: succession and body size, management by cutting and sowing. - Oecologia 98: 8-14.

Gathmann, A. 1998. Bienen, Wespen und ihre Gegenspieler in der Agrarlandschaft: Artenreichtum und Interaktionen in Nisthilfen, Aktionsradien und Habitatbewertung. - Cuvilier Verlag, Göttingen.

Grimm, V. et al. 1999. Individual-based modelling and ecological theory: synthesis of a workshop. - Ecol. Model. 115: 275-282.

Krombein, K. V. 1967. Trap-nesting wasps and bees: life histories, nests, and associates. - Smithonian Press, Washington.

Maddocks, R. and Paulus, H. F. 1987. Quantitative Aspekte der Brutbiologie von Osmia rufa L. und Osmia cornuta Latr. (Hymenoptera: Megachilidae) - eine vergleichende Untersuchung zu Mechanismen der Konkurrenzminderung zweier nahverwandter Bienenarten. [Quantitative aspects of the breeding biology of Osmia rufa and Osmia cornuta: a comparative study of competition-reducing mechanisms in two closely related bee species.] - Zoologische Jahrbücher, Abt. f. Systematik, Ökologie und Geographie der Tiere 114: 15-44.

Phillips, J. K. and Klostermeyer, E. C. 1978. Nesting behavior of Osmia lignaria propinqua Cresson (Hymenoptera: Megachilidae). - J. Kans. Entomol. Soc. 51: 91-108.

Raw, A. 1972. The biology of the solitary bee Osmia rufa (L.) (Megachilidae). - Trans. R. Entomol. Soc. Lond. 124: 213229.

Rosenheim, J. A., Nonacs, P. and Mangel, M. 1996. Sex ratios and multifaceted investment. - Am. Nat. 148 (3): 501-533.

Schwenninger, H. R. 1992. Investigations on the influence of intensity of cultivation in rural areas on the occurence of insects, with special reference to the wild bees (Hymenoptera: Apoidea) - Zoologische Jahrbücher, Abt. f. Systematik, Ökologie und Geographie der Tiere 119: 543-561. 
Seidelmann, K. 1995. Untersuchungen zur Reproduktionsbiologie der Roten Mauerbiene, Osmia rufa (L. 1758). - Dissertation, Univ. Halle.

Seidelmann, K. 1999. The function of the vestibulum in nests of a solitary stem-nesting bee, Osmia rufa (L.). - Apidologie 30: 19-29.

Tepedino, V. J. and Torchio, P. F. 1989. Influence of nest hole selection on sex ratio and progeny size in Osmia lignaria propinqua (Hymenoptera: Megachilidae). - Ann. Entomol. Soc. Am. 82: 355-360.

Ulbrich, K. and Seidelmann, K. 1998. Hat die Körpergröße einen Einfluß auf das Nistverhalten? Vorbereitung eines Computermodells zu Osmia rufa. - Informationen aus Naturund Artenschutz 1/98: 27-32.
Ulbrich, K. and Henschel, J. R. 1999. Intraspecific competition in a social spider. - Ecol. Model. 115: 243-251.

Ulbrich, K. et al. 1999. Einfluss individuellen Verhaltens auf die Populationsdynamik. Ein individuen-basiertes Modell zu Wildbienen. - Mitt. Dt. Ges. Ang. Allg. Entomol., in press. Westrich, P. 1989. Die Wildbienen Baden-Württembergs. - Ulmer, Stuttgart. 